\title{
HAWAII GROUND-WATER QUALITY
}

By Johnson J.S. Yee

U.S. Geological Survey Open-File Report 87-0721 
DEPARTMENT OF THE INTERIOR

DONALD PAUL HODEL, Secretary

\section{U.S. GEOLOGICAL SURVEY}

Dallas L. Peck, Director

For additional information:

Chief Hydrologist

U.S. Geological Survey

407 National Center

Reston, VA 22092
For sale by:

U.S. Geological Survey

Books and Open-File Reports Section Federal Center

Box 25425

Denver, Colorado 80225

Use of trade names in this report is for descriptive purposes only and does not constitute endorsement by the U.S. Geological Survey 


\section{FOREWORD}

This report contains summary information on ground-water quality in one of the 50 States, Puerto Rico, the Virgin Islands, or the Trust Territories of the Pacific Islands, Saipan, Guam, and American Samoa. The material is extracted from the manuscript of the 1986 National Water Summary, and with the exception of the illustrations, which will be reproduced in multi-color in the 1986 National Water Summary, the format and content of this report is identical to the State ground-water-quality descriptions to be published in the 1986 National Water Summary. Release of this information before formal publication in the 1986 National Water Summary permits the earliest access by the public. 


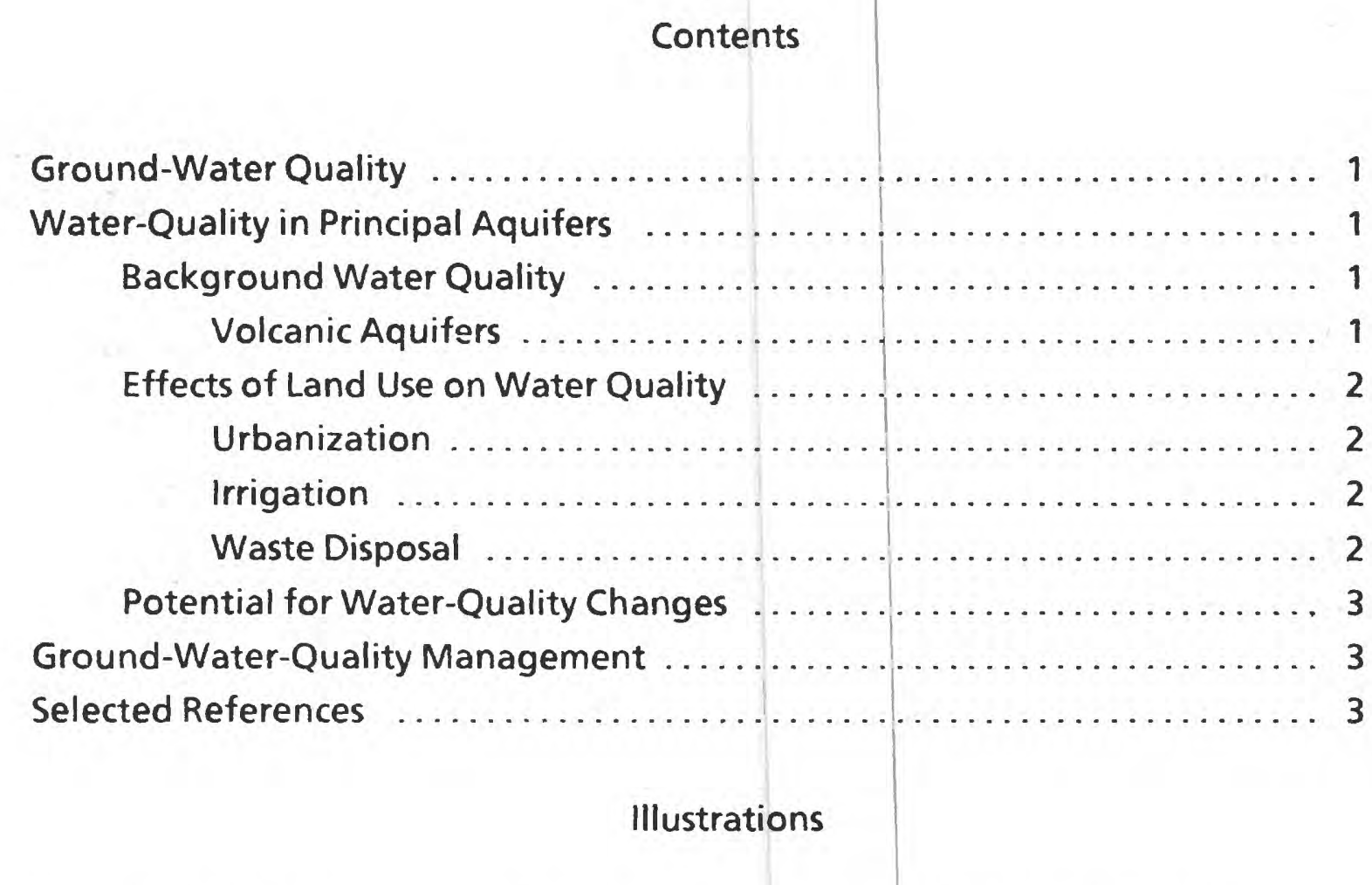

Figure 1.--Selected geographic features and 1985 population distribution in Hawaii.

Figure 2.--Principal aquifers and related water-quality data in Hawaii.

Figure 3.--Selected waste sites in Hawaii, 1986.

Figure 4.--Long-term fluctuations of hardness and chloride concentrations in selected wells in Oahu, Hawaii, 1959-85. 


\section{HAWAII Ground-Water Quality}

Hawaii consists of 132 islands, shoals, and reefs (fig. 1). The State extends more than 1,600 miles across the central Pacific Ocean, and occupies $6,451 \mathrm{mi}^{2}$ (square miles) in a northwest to southeast orientation. The eight major islands, comprising 99.9 percent of the land, in decreasing size are: Hawaii $\left(4,038 \mathrm{mi}^{2}\right)$, Maui $\left(729 \mathrm{mi}^{2}\right)$, Oahu $\left(608 \mathrm{mi}^{2}\right)$, Kauai $\left(553 \mathrm{mi}^{2}\right)$, Molokai $\left(261 \mathrm{mi}^{2}\right)$, Lanai (139 $\left.\mathrm{mi}^{2}\right)$, Nihau (73 $\left.\mathrm{mi}^{2}\right)$, and Kahoolawe (45 $\left.\mathrm{mi}^{2}\right)$ (U.S. Geological Survey, 1986, p. 201).

Ground water is the major source for public supply in Hawaii, and about 95 percent of the population (fig. $1 B$ ) depends on ground water. All ground water developed for public supplies does not exceed drinking-water standards recommended by the Hawaii State Department of Health (DOH) for dissolved solids, chloride, and nitrate. In the major areas of public-supply withdrawals, the median concentration of dissolved solids is smaller than $1,000 \mathrm{mg} / \mathrm{L}$ (milligrams per liter), and in all areas, the median nitrate concentration, reported as nitrogen, does not exceed the recommended maximum of $10 \mathrm{mg} / \mathrm{L}$ (fig. $2 \mathrm{C}$ ). However, saltwater intrusion, on a regional or local scale, is a potential problem because most of Hawaii's ground water resides as a freshwater lens (referred to locally as basal water), floating on the underlying saltwater, in a highly permeable and porous aquifer. Two percent contamination of the aquifer by seawater will increase the chloride concentration of the water in the aquifer to exceed the secondary drinking water standard of $250 \mathrm{mg} / \mathrm{L}$. Degradation of water quality in several areas is associated with use of organic compounds including ethylene dibromide (EDB), dibromochloropropane (DBCP), trichloropropane (TCP), trichloroethylene (TCE), perchloroethylene (PCE), and atrazine. Contamination of drinking-water sources by these synthetic chemicals has been confirmed by the DOH. At present, about 10 wells have been removed from service as a drinking-water supply because of contamination by EDB or DBCP at concentrations larger than $0.02 \mu \mathrm{g} / \mathrm{L}$ (micrograms per liter), and TCE at concentrations larger than $2.8 \mu \mathrm{g} / \mathrm{L}$. These are the levels at which the DOH recommends a review for alternative sources or treatment of the water. In some instances, treatment plants have been installed to remove the contaminants before the water is used for public supply.

There are no active hazardous-materials disposal sites located in Hawaii. Three nonhazardous industrial sites (fig. 3) regulated under the Federal Resources Conservation and Recovery Act (RCRA) of 1976. Six well sites ("other" sites in fig. 3) on Oahu have been proposed for inclusion in the National Priorities List (NPL) for evaluation under the Comprehensive Environmental Response, Compensation, and Liability Act (CERCLA) of 1980 (U.S. Environmental Protection Agency, 1986c). In addition, the U.S. Department of Defense (DOD) has identified four sites at one facility where contamination has warranted remedial action.

In 1969, the U.S. Geological Survey, in cooperation with Hawaii State Department of Land and Natural Resources (DLNR), began a ground-water-quality observation program to monitor chloride concentration as a measure of saltwater intrusion into basal aquifers. By 1986, the program included measurements at more than 154 wells. In addition to monitoring chloride concentrations, the program has included limited data collection for inorganic and organic constituents. From 1984 to 1986 , organic constituents were measured at 85 sites by the U.S. Geological Survey, in cooperation with the $\mathrm{DOH}$, to determine organic priority pollutants in ground water. Organic constituents, however, have been measured at specific sites where presence of pesticides has prompted investiga- tions by State and county agencies, and by the pineapple and sugar industries.

\section{WATER QUALITY IN PRINCIPAL AQUIFERS}

Eighteen aquifers have been identified on the six islands of Kauai, Oahu, Molokai, Lanai, Maui, and Hawaii (U.S. Geological Survey, 1985, p. 185). Among these are the principal volcanic aquifers that yield large quantities of water: Napali volcanic rocks in the Kekaha-Mana area, Kauai; Koolau volcanic rocks in central Oahu and Honolulu areas; East Molokai volcanic rocks in Molokai; Honolua volcanic rocks in west Maui; Kula volcanic rocks in central Maui; and Kau volcanic rocks in the Hilo area, Hawaii (fig. $2 A$ ).

Fresh ground water extends below sea level in porous volcanic rocks, floating as a freshwater lens in equilibrium with the underlying denser saline water. The lens is maintained by recharge. Whenever recharge is decreased, thinning of the lens occurs and subsequently seawater can encroach. In Hawaii, saltwater encroachment is the most common pollutant of freshwater. Many of Hawaii's ground-water problems are in some way connected to the encroachment of saline water induced by development and pumping of the aquifers (Takasaki, 1978, p. M1). Other ground-water bodies, small in comparison, are perched or isolated from the basal freshwater aquifers by intrusive dikes.

The freshest ground water in Hawaii, commonly containing less than $500 \mathrm{mg} / \mathrm{L}$ dissolved solids, occurs in the interior of the islands. At the outer rim of the islands, the dissolved-solids concentration in ground water exceeds $1,000 \mathrm{mg} / \mathrm{L}$; below the freshwater lenses, dissolved-solids concentrations of the ground water approach those of seawater.

\section{BACKGROUND WATER QUALITY}

A graphic summary of selected water-quality variables compiled from the U.S. Geological Survey's National Water Data Storage and Retrieval System (WATSTORE) is presented in figure $2 B$. The summary is based on dissolved-solids, hardness (as calcium carbonate), nitrate (as nitrogen), and silica analyses of water samples collected from 1969 to 1985 from the principal aquifers in Hawaii. Percentiles of these variables are compared to national standards that specify the maximum concentration or level of a contaminant in drinking-water supply as established by the U.S. Environmental Protection Agency $(1986 a, b)$. The primary maximum contaminant level standards are health related and are legally enforceable. The secondary maximum contaminant level standards apply to esthetic qualities and are recommended guidelines. The primary drinking-water standards include a maximum concentration of 10 $\mathrm{mg} / \mathrm{L}$ nitrate (as nitrogen), and the secondary drinking-water standards include a maximum concentration of $500 \mathrm{mg} / \mathrm{L}$ for dissolved solids. The summary was limited to volcanic aquifers because of their importance as water supplies. The data base is not adequate to make statistical inferences for other aquifers. The data were interpreted without distinction as to sample depth within the aquifer, and where more than one analysis was available, the median concentration for a site was used.

\section{Volcanic Aquifers}

In the Koolau volcanic aquifers on Oahu (fig. $2 B$, aquifers 2 and 3 ), where most water for public supply is withdrawn, the median concentration of dissolved solids does not exceed the 
secondary drinking-water standard of $500 \mathrm{mg} / \mathrm{L}$. Although this limit does not apply to irrigation water, large concentrations of dissolved solids or salinity make the water less desirable for irrigation or other uses. Water from the Maui volcanic aquifers (fig. $2 B$, aquifers 4 and 5) is used principally for irrigation; the median concentration of dissolved solids exceeds $500 \mathrm{mg} / \mathrm{L}$.

Calcium and magnesium, which contribute to the hardness of water, are among the soluble minerals in water from volcanic aquifers. Generally, the larger the concentration of dissolved solids, the greater is the hardness (fig. $2 B$ ). Hardness concentration is largest on Maui and Kauai, where the water is used mostly for irrigation. Hardness concentration for all public supplies is generally smaller than $120 \mathrm{mg} / \mathrm{L}$, which is classified as moderately hard.

In water from all volcanic aquifers (fig. $2 B$, aquifers $1-6$ ), the median value of nitrate (as nitrogen) is smaller than $10 \mathrm{mg} / \mathrm{L}$. No nitrate concentrations in ground water exceed this standard. In Hawaii, nitrate concentrations larger than about $1.1 \mathrm{mg} / \mathrm{L}$ (as nitrogen) indicate contamination by human activities (Swain, 1973, p. 5). Studies have indicated that increased nitrate concentrations in ground water are directly correlated with areas of irrigation.

The median concentration for silica is larger than $30 \mathrm{mg} / \mathrm{L}$ in all waters from the volcanic aquifers (fig. $2 C$ ). Silica in water is undesirable for a number of industrial uses, because in the presence of calcium and magnesium it forms scale, especially in boilers and steam turbines.

\section{EFFECTS OF LAND USE ON WATER QUALITY}

Water quality has deteriorated in some areas because of the effects of urbanization, irrigation, and waste disposal. Investigation by the U.S. Geological Survey and interpretation of data collected by the Honolulu Board of Water Supply have documented declines in ground-water levels and increases in chloride concentration in Oahu's aquifers. Examples of the effects of urbanization on the chloride concentration in ground water are shown in figure 4.

\section{Urbanization}

Considerable ground-water development occurred, especially in southern Oahu, after the first successful well was drilled in 1879. During the 50 years that followed, water from wells near the coast in southern Oahu, once of good quality, became brackish. The ground-water level in the Honolulu area of Oahu, which once stood as high as 43 feet above sea level, steadily declined to about 25 feet above sea level (Takasaki, 1978). It is estimated from the Ghyben-Herzberg principle, that for the long-term loss of every foot of freshwater above sea level, there is a concurrent loss of about 40 feet of freshwater below sea level. The loss of freshwater is actually greater than 40 feet because of mixing of the fresh and saltwaters that causes a thickening of the transition zone between the two waters.

Among the major islands, Oahu has experienced unparalleled urban growth since statehood in 1959. To accommodate this growth, many agricultural lands were developed and urbanized. Because of this change in land use, much of the recharge from both irrigation and precipitation that normally would percolate into the water table in agricultural lands is now lost by evaporation or flows into storm drains away from the recharge area. The additional demands for water also led to increased pumping, which caused local upconing of the saline water and larger concentrations of dissolved solids.

\section{Irrigation}

The large use of ground water for irrigation in Hawaii has contributed to water-quality changes. Intensive pumping of the basal freshwater has caused local upconing of the underlying saline water, resulting in larger chloride concentrations. Irrigating with water containing larger chloride concentrations further increases the chloride concentration in the freshwater lens, as excess water percolates back to the water table. Eyre (1983) reported an increase of chloride concentration from 178 to $290 \mathrm{mg} / \mathrm{L}$ in water used as a potable supply in central Oahu. The increase of chloride concentration over a 7-year period was attributed to brackish irrigationreturn water recharging the freshwater aquifer.

Application of fertilizer and other chemicals to the surface adds soluble products to the ground water, but at present, few chemicals have been detected in excess of the limits recommended for drinking water. However, pesticides and other organic compounds have reached the basal aquifers. The State has closed 10 wells that yield contaminated water (fig. $3 B$ ) in central Oahu and has directed remedial action to eliminate DBCP and EDB in drinking water sources having concentrations larger than $0.02 \mu \mathrm{g} / \mathrm{L}$. Two granulated active carbon (GAC) filtration units are operated by the Honolulu Board of Water Supply to remove DBCP, EDB, and TCP. The U.S. Army is operating an air-stripping unit to remove TCE in water pumped from the Schofield wells.

\section{Waste Disposal}

Waste sites in Hawaii are associated mainly with private and county landfills (fig. 3C) that are used to dispose of industrial and domestic solid wastes. Most military waste sites have been discontinued and have been replaced with private-contracting disposal services. Very few data are being collected to evaluate the effects of active or inactive landfill sites on ground-water quality. Fortunately, most landfills are located away from ground-water recharge areas. Trace metals and organic chemicals commonly associated with landfills have not been detected in potable ground-water supplies. Hawaii lacks heavy urban and industrial densities that produce the type of heavy pollutant loads found in various parts of the continental United States. Furthermore, plans are being made to build and operate a garbage-to-energy plant in Honolulu that will further reduce the waste loading to landfills on Oahu.

There is no evidence that current surface impoundment activities are any threat to existing drinking water sources (Hawaii State Department of Health, 1980). This is due, in part, to the location of sites generally down-gradient and sufficient distances from drinking-water sources, and to the composition of the wastes going into impoundments.

As of September 1985, 32 hazardous-waste sites at 7 facilities in Hawaii had been identified by the U.S. Department of Defense (DOD) as part of their Installation Restoration Program (IRP) as having potential for contamination (U.S. Department of Defense, 1986). The IRP, established in 1976, parallels the U.S. Environmental Protection Agency's (EPA) Superfund program under the Comprehensive Environmental Response, Compensation, and Liability Act (CERCLA) of 1980. EPA presently ranks these sites under a hazard ranking system and may include them in the NPL. Four sites at one facility (fig. 3A) were considered to present a hazard significant enough to warrant response action in accordance with CERCLA. The remaining sites were scheduled for confirmation studies to determine if remedial action is required.

There are no hazardous-waste disposal sites in Hawaii operating under RCRA regulations. All hazardous and toxic materials are currently transported by commercial contractors out of the state. RCRA sites are mainly industrial-related sites where chemicals are used for cooling or treating wastewater. There are two electric generating stations and one petroleum refinery on Oahu (fig. $3 A$ ) that are regulated by RCRA guidelines.

Six well sites ("other" sites in fig. $3 A$ ) have been proposed for inclusion on the NPL (U.S. Environmental Protection Agency, 1986c), because of contamination of the water by DBCP, EDB, TCE, and TCP. EPA has not made any final decisions on these CERCLA (Superfund) sites, and will retain them on its proposed list for future 
cleanup consideration. The sites are within the Koolau volcanic aquifer in central Oahu.

\section{POTENTIAL FOR WATER-QuALITY CHANGES}

Pesticides and chemicals have been reported in Hawaii's ground water other than those found in central Oahu's wells that yield contaminated water. Some are agricultural pesticides, and others may be decomposition products. Concentrations of many reported organic compounds, which have no established drinkingwater standards, range from 0.02 to $0.20 \mu \mathrm{g} / \mathrm{L}$. The potential danger of these chemicals has been recognizad, and the $\mathrm{DOH}$ is developing strategies to monitor all frequently used and suspected compounds found in Hawaii's waters. Organic compounds detected and confirmed by the $\mathrm{DOH}$ in ground water include atrazine, carbon tetrachloride, DBCP, dichloropropane, dichloropropene, EDB, PCE, and TCP.

\section{GROUND-WATER-QUALITY MANAGEMENT}

The Hawaii DOH administers programs to protect the quality of ground water. Monitoring of ground-water quality for compliance with the Safe Drinking Water Act is performed by the State's Safe Drinking Water Program. This program monitors for those contaminants identified in Chapter 20, Title 11, Administrative Rules (Hawaii State Department of Health, 1981). The program attempts to ensure that water from public water systems meets all drinking-water standards. In the past, this program has monitored unregulated compounds in ground and surface waters, and in potable and nonpotable waters on a statewide basis.

Because of the agricultural activities in Hawaii, much of the emphasis in ground-water protection from pesticide usage is vested in the Pesticides Branch of the Hawaii State Department of Agriculture (DOA) for enforcement of rules for permit and application of pesticides. Monitoring of soils and water for the presence of pesticides has been undertaken by the Pesticides Branch with assistance from the Drinking Water Program and the Laboratories Branch of the DOH.

The Hawaii State Office of Environmental Quality Control (OEQC) has been directed by Act 127, Hawaii Session Law 1985, to coordinate and develop a systematic plan to monitor Hawaii's ground and surface waters. Short- and long-term strategies are being developed first to monitor drinking-water sources and then all other waters. The plan, to be completed by October 1, 1987, will report on which chemicals are frequently used, how toxic they are, how likely they are to enter into ground-water sources, and what efforts are needed to monitor the water resources.

The island character of the State, combined with the relatively fast population growth, requires that water quantity and availability be carefully monitored. This responsibility rests with the DLNR. The DLNR enforces Chapter 177, Hawaii Revised Statutes (HRs) which empowers it to control water withdrawals in areas of groundwater shortage. Currently, DLNR has designated areas in the Koolau volcanic aquifers of Waialua, Pearl Harbor, and Honolulu on Oahu as control areas to prevent depletion, waste pollution, or deterioration by saltwater encroachment. Permits for drilling wells on Oahu are required by the DLNR or the Honolulu Board of Water Supply.

\section{SELECTED REFERENCES}

Eyre, P.R., 1983, The effects of pumpage, irrigation return, and regional ground-water flow on the water quality at Waiawa water tunnel, Oahu, Hawaii: U.S. Geological Survey Water-Resources Investigations Report 83-4097, 44 p.

Hawaii State Department of Health, 1980, Surface impoundment assessment: Hawaii State Department of Health, Honolulu, Hawaii, 181 p. 1981, Chapter 20 of title 11, administrative rules, entitled, "Potable water systems", 39 p.

Solley, W.B., Chase, E.B., and Mann, W.B., IV, 1983, Estimated water use in the United States in 1980: U.S. Geological Survey Circular $1001,56 \mathrm{p}$.

Stearns, H.T., and Macdonald, G.A., 1942a, Geology and ground-water resources of the island of Maui, Hawaii: Hawaii Division of Hydrography Bulletin 7, 344 p. 1942b, Geology and ground-water resources of the island of Hawaii: Hawaii Division of Hydrography Bulletin 9, $363 \mathrm{p}$. 1942c, Geology and ground-water resources of the island of Oahu, Hawaii: Hawaii Division of Hydrography Bulletin 1, 479 p.

Swain, L.A., 1973, Chemical quality of ground water in Hawaii: Hawaii Division of Water and Land Development, Report R48, 54 p.

Takasaki, K.J., 1978, Summary appraisals of the nation's ground-water resources-Hawaii region: U.S. Geological Survey Professional Paper 813-M, 29 p.

U.S. Department of Defense, 1986, Status of the Department of Defense installation restoration program-Information paper: Washington, D.C., U.S. Department of Defense, Office of the Assistant Secretary of Defense (Acquisition and Logistics), Environmental Policy Directorate, February, 35 p.

U.S. Environmental Protection Agency, 1986a, Maximum contaminant levels (subpart B of part 141, National interim primary drinking-water regulations): U.S. Code of Federal Regulations, Title 40, Parts 100 to 149 , revised as of July 1,1986 , p. $524-528$.

1986b, Secondary maximum contaminant levels (section 143.3 of part 143, National secondary drinking-water regulations): U.S. Code of Federal Regulations, Title 40, Parts 100 to 149 , revised as of July 1, 1986, p. 587-590.

1986c, Amendment to national oil and hazardous substances contingency plan; national priorities list, final rule and proposed rule: Federal Register, v. 51, no. 111, June 10, 1986, p. 21053-21112.

U.S. Geological Survey, 1985, National water summary, 1984-Hydrologic events, selected water-quality trends, and ground-water resources: U.S. Geological Survey Water-Supply Paper 2275, 467 p.

1986, National water summary, 1985-Hydrologic events and surface-water resources: U.S. Geological Survey Water-Supply Paper 2300, $506 \mathrm{p}$. 

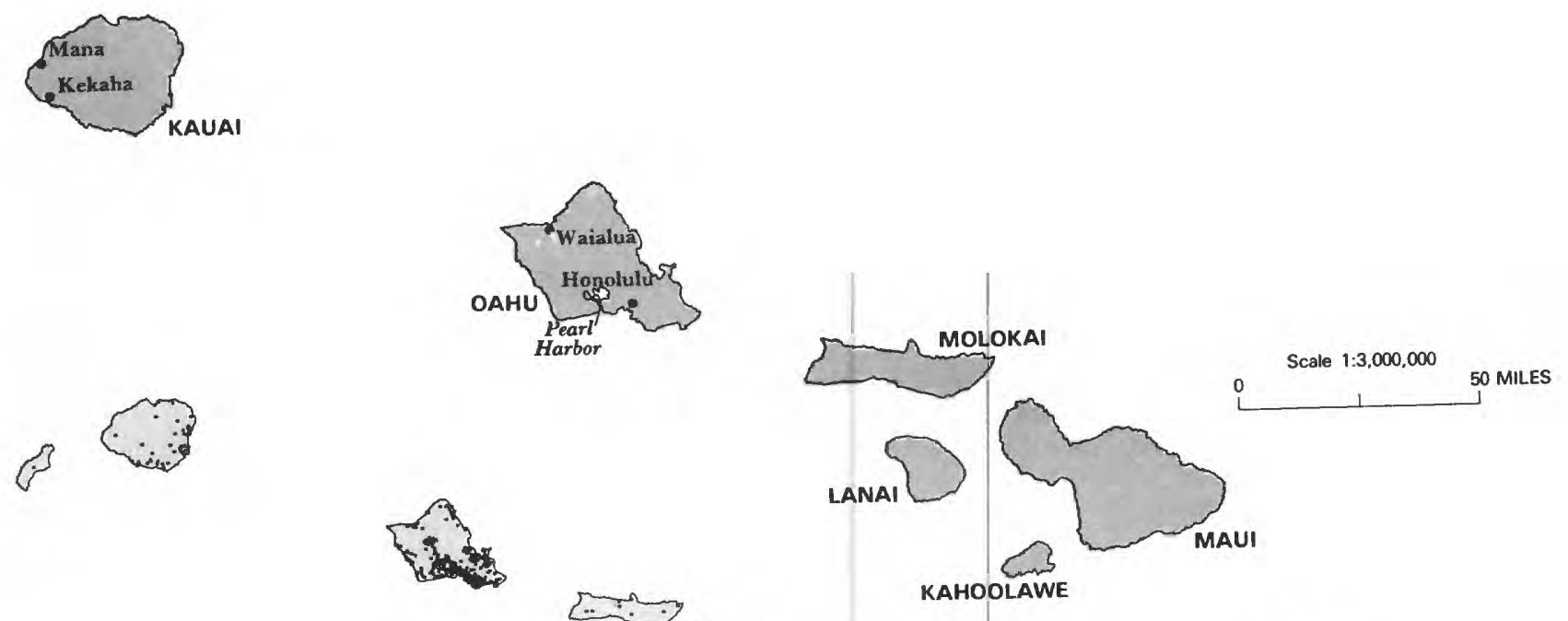

Figure 1. Selected geographic features and 1985 population distribu-
tion in Hawaii. A, Islands, selected cities, and major drainages. B. Popula-
tion distribution, 1985 ; each dot on the map represents 1,000 people. Source:
B, Data from U.S. Bureau of the Census 1980 decennial census files, ad-
justed to the 1985 U.S. Bureau of the Census data for county populations.) 

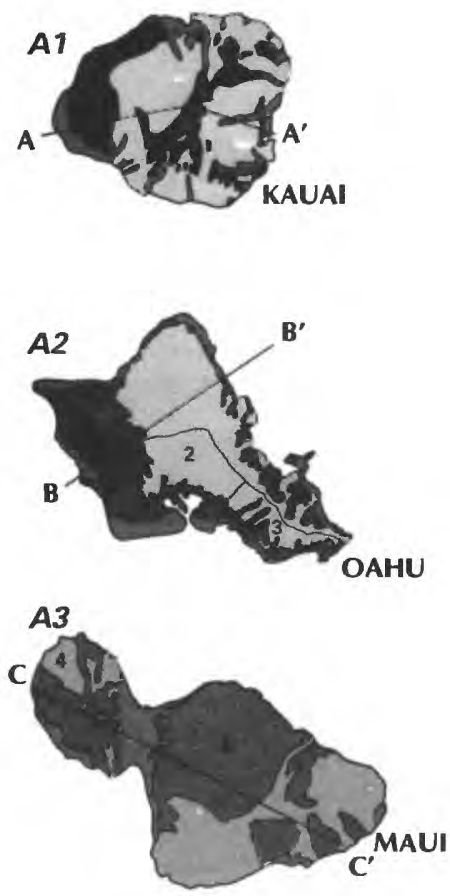

C WATER-QUALITY DATA

Percentile - Percentage of analyses equal to or less than indicated values 1-90th

-75 th
-50 th
-25 th

National drinking-water standards - Maximum permissible contaminant level (primary)

- _ Maximum recommended contaminant level isecondaryl Reporting limit

.. Minimum reporting level with analytical method used

NUMBER OF ANALYSES

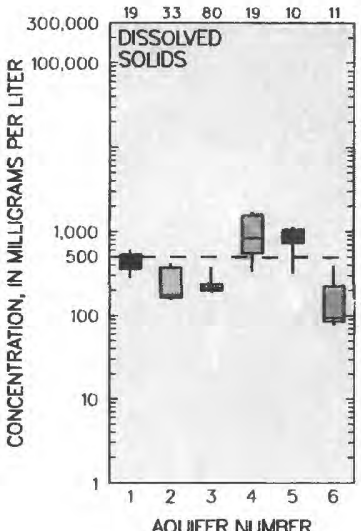

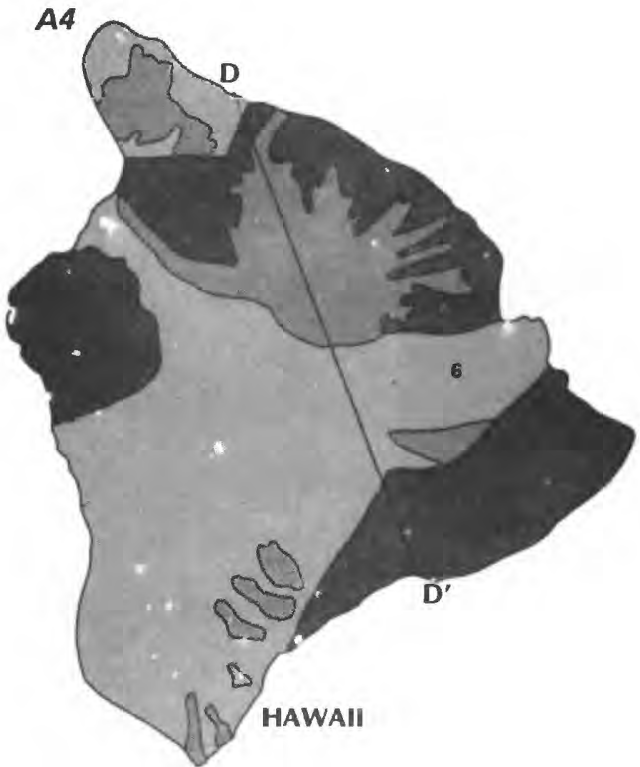

PRINCIPAL AQUIFER - Numeral is aquifer number in figure $2 \mathrm{C}$ ALL ISLANDS

Sedimentary material KAUAI

Napali volcanic (1)

Koloa and Olokele volcanic aquifers OAHU

Alluvial

Koolau volcanic $(2,3)$

Waianae and Honolulu volcanic aquifers MAUI

Honolua and Hana volcanic aquifers Honolua volcanic (4)

Kula and Wailuku volcanic aquiters Kula volcanic (5)

HAWAII

Kau and Pololu volcanic aquifers Kau volcanic (6)

Puna, Hualalai, Kahuku, and Hamakua volcanic aquifers

Laupahoehoe and Hawi volcanic

A-A' Trace of hydrogeologic section Horizontal scale of section $3 \mathrm{X}$ map scale, except Hawaii
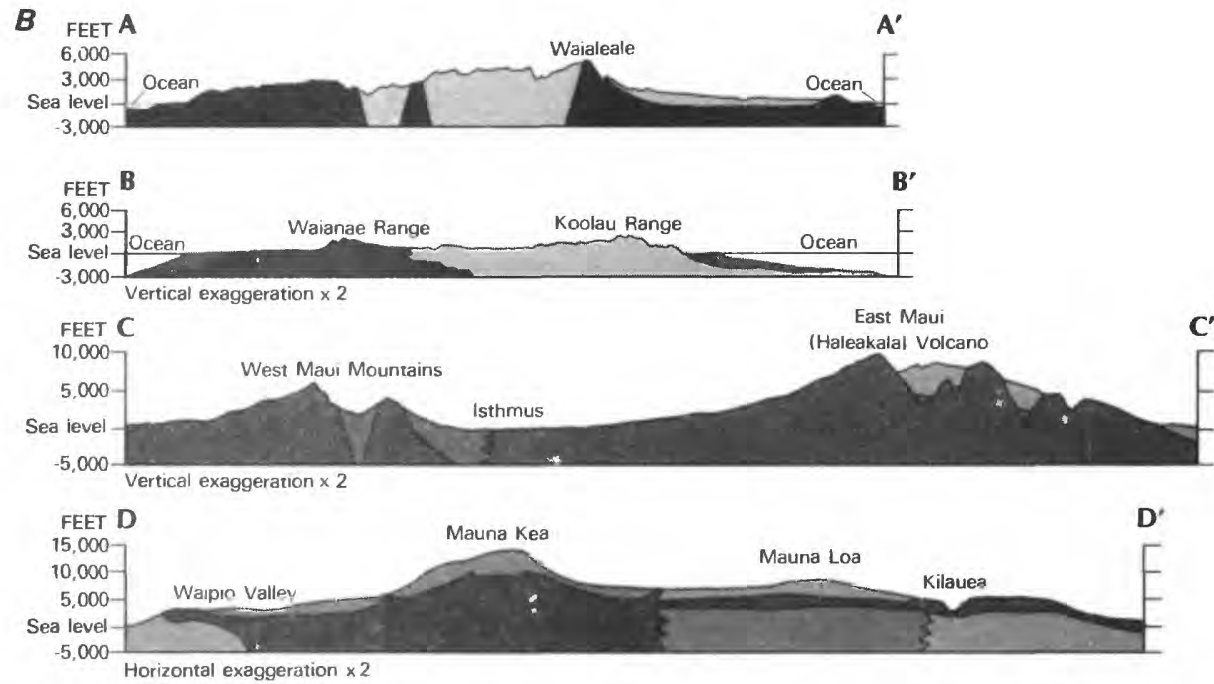

NUMBER OF ANALYSES

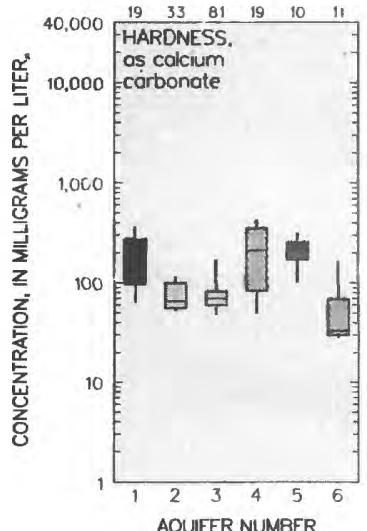

NUMBER OF ANALYSES

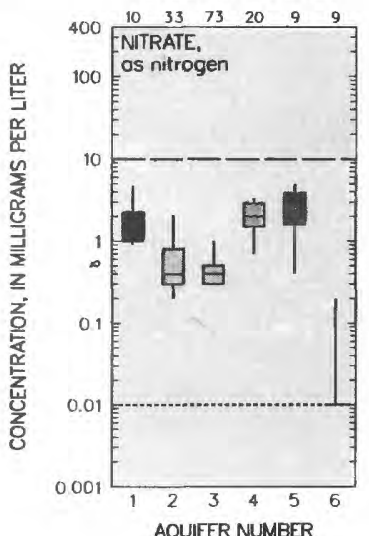

NUMBER OF ANALYSES

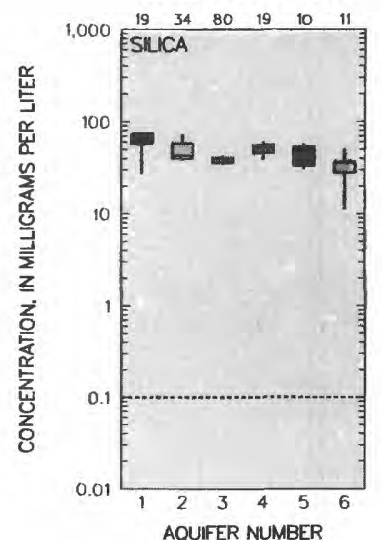

Figure 2. Principal aquifers and related water-quality data in Hawaii. $\quad \boldsymbol{A}$, Principal aquifers and generalized hydrogeologic sections: $\boldsymbol{A} 1$, Kauai; $\boldsymbol{A 2}$, Oahu; A3. Maui; A4, Hawaii. B. Selected water-quality constituents and properties, as of 1969-85. (Sources: A, U.S. Geological Survey, 1985; Stearns and Macdonald, 1942; modified from Takasaki, 1978. B. Analyses compiled from U.S. Geological Survey files; national drinking-water standards from U.S. Environmental Protection Agency, 1986a,b.) 
WASTE SITE - Numeral indicates more than one site at same general location - RCRA (Superfund) 4 IaP

- Other

\section{GROUND-WATER QUALITY}

- Well that yields contaminated water

\section{LANDFHLL SITE}

Private and county landfills, by county Active and inactive

No data

$\square$ 1-3

4-10
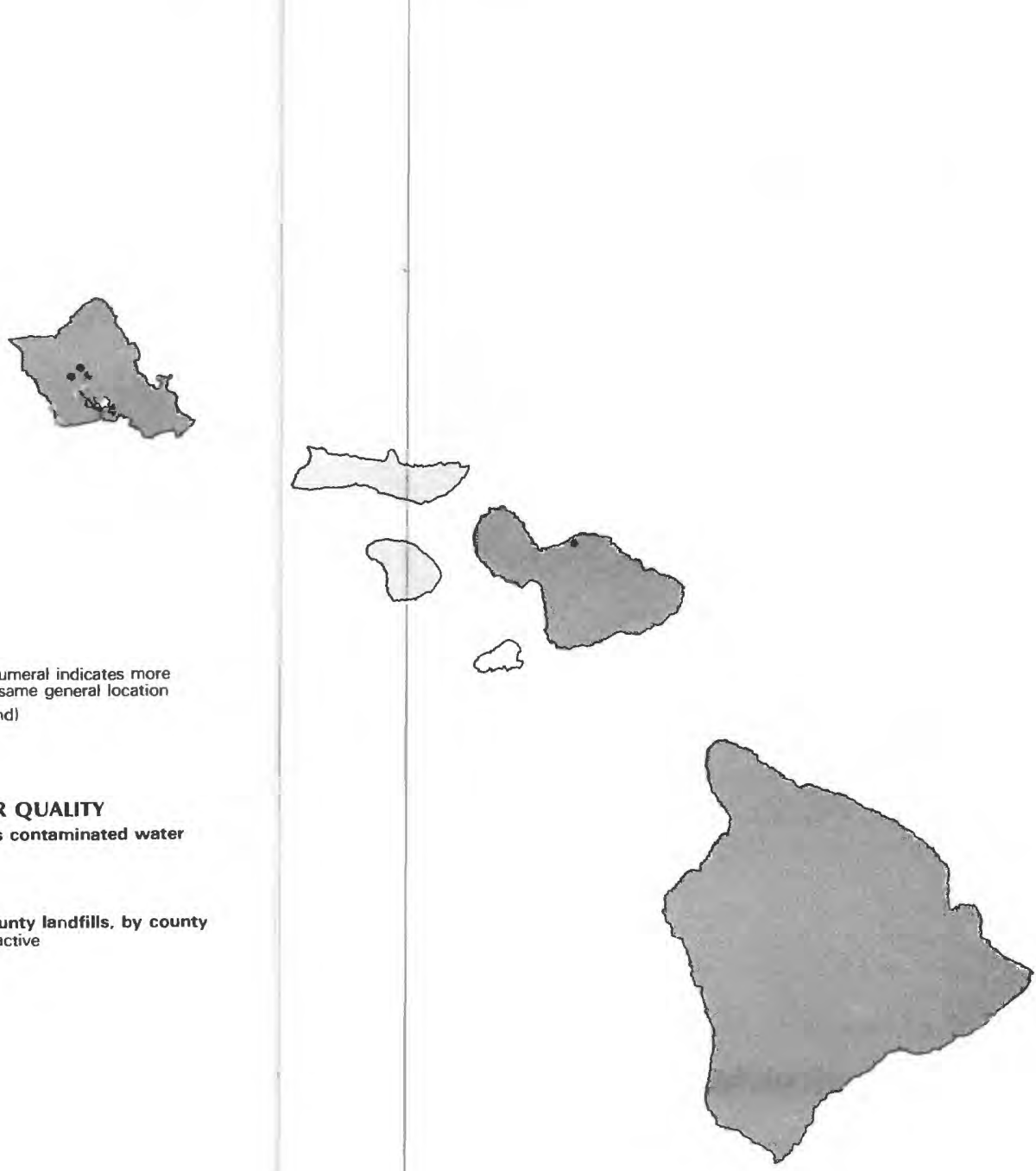

Figure 3. Selected waste sites in Hawaii, 1986. Resource Conservation and Recovery Act (RCRA) sites as of 1985; Department of Defense Installation Restoration Program (IRP) sites as of 1985 and other selected waste sites, as of 1986; distribution of wells that yield contaminated water, as of 1985; private and county landfills, as of 1985. (Sources: Hawaii State Department of Health records; U.S. Department of Defense, 1986; U.S. Environmental Protection Agency, 1986c.) 

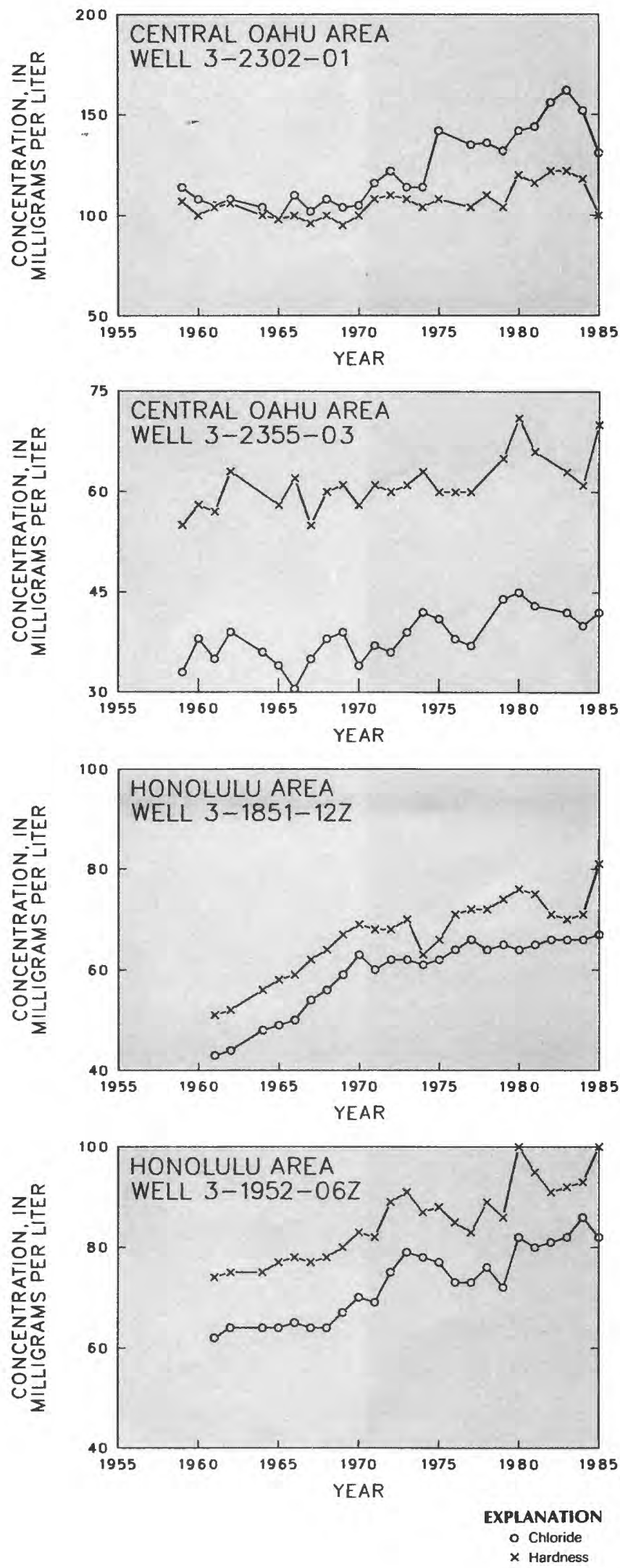

Figure 4. Long-term fluctuations of hardness and chloride concentrations in selected wells in Oahu, Hawaii, 1959-85. (Sources: C.E. Miyaji and S.E. Miyamoto, U.S. Geological Survey, written commun., 1986.I 